\title{
7. UPPER CRETACEOUS CARBON- AND OXYGEN-ISOTOPE STRATIGRAPHY OF DEEP-WATER SEDIMENTS FROM THE NORTH-CENTRAL PACIFIC (SITE 869, FLANK OF PIKINNI-WODEJEBATO, MARSHALL ISLANDS) ${ }^{1}$
}

\author{
H.C. Jenkyns, ${ }^{2}$ J. Mutterlose, ${ }^{3}$ and W.V. Sliter ${ }^{4}$
}

\begin{abstract}
Carbon- and oxygen-isotope data from the Cenomanian through Maastrichtian section of Site 869 (flank of Pikinni-Wodejebato, formerly Bikini-Sylvania) show trends that compare favorably with those documented from other parts of the world and also show that adequate interchange took place between the paleo-Pacific and other parts of the world ocean. The Cenomanian/ Turonian boundary $\delta^{13} \mathrm{C}$ "spike," followed by a broad trough in the Turonian/Coniacian, is recognizable. However, some stratigraphic inconsistencies are seen between Pacific and European sites in terms of the placing of the stage boundaries if the isotope curve is used as a reference. Some negative excursions in the Campanian interval, particularly those that correlate with similar trends in the oxygen-isotope ratios, may be diagenetic artifacts. However, a well-defined $0.5 \%$ decrease in values close to the stage boundary with the Maastrichtian may be real, as a similar phenomenon has been documented from elsewhere in the Pacific, from sites off Antarctica, and from northern Europe. The oxygen-isotope data show a minimum near the Cenomanian/Turonian boundary and an irregular rise thereafter, in agreement with trends observed elsewhere and consistent with the hypothesis of global climatic deterioration during post-Cenomanian time.
\end{abstract}

\section{INTRODUCTION AND PREVIOUS WORK}

Site 869 , situated on the flank of the atoll-guyot pair Pikinni-Wodejebato (formerly Bikini-Sylvania) in the Marshall Islands chain (Figs. $1,2)$, contains a thick section of Cretaceous redeposited volcaniclastic and shallow-water material. Enough planktonic foraminiferal and nannofossil carbonate is present to allow dating to the stage level, and the Cenomanian, Turonian, Coniacian, Santonian, Campanian, and Maastrichtian stages can all be recognized (Sager, Winterer, Firth, et al., 1993). Since stable-isotopic records from the mid-Cretaceous of the Pacific region are so sparse, it was considered useful to analyze this carbonate in an attempt to generate an interpretable record and to compare it with the chemostratigraphy already established from welldated sections in northern and southern Europe. However, the planktonic component of the core is heavily outweighed by altered volcaniclastic debris (Fig. 3) and the facies are far from ideal.

Carbon- and oxygen-isotope signatures of Upper Cretaceous pelagic carbonate sections were first defined by the pioneering work of Scholle and Arthur (1980). Their investigations in Europe and Central America indicated a pronounced positive $\delta^{13} \mathrm{C}$ excursion that centered at the Cenomanian/Turonian boundary, followed by an irregular decline. Later work has confirmed the ubiquitous character of the Cenomanian-Turonian isotopic event (Pratt and Threlkeld, 1984; Schlanger et al., 1987; Jarvis et al., 1988; Kuhnt et al., 1990), and expanded sections show clearly that at least a three-pronged peak is present, of which only the highest part lies within the Turonian (Gale et al., 1993). The genesis of this positive $\delta^{13} \mathrm{C}$ excursion is conventionally explained in terms of regional excess organic-carbon burial, a phenomenon (oceanic anoxic event) for which there is a globally distributed record of black shales (Jenkyns, 1980; Schlanger et al., 1987; Arthur et al., 1990). Given that organic carbon is enriched in the lighter isotope ${ }^{12} \mathrm{C}$, as compared to that found in the oceanatmosphere system as carbonate or $\mathrm{CO}_{2}$, its escape by burial from

\footnotetext{
${ }^{1}$ Winterer, E.L., Sager, W.W., Firth, J.V., and Sinton, J.M. (Eds.), 1995. Proc. ODP Sci. Results, 143: College Station, TX (Ocean Drilling Program).

${ }^{2}$ Department of Earth Sciences, University of Oxford, Parks Road, Oxford OX1 3PR, United Kingdom.

${ }^{3}$ Institut für Geologie, Ruhr-Universităt Bochum, Universitătsstrasse 150, D-448011 Bochum, Federal Republic of Germany.

${ }^{4}$ U.S. Geological Survey, Branch of Paleontology, M/S 915, 345 Middlefield Road, Menlo Park, CA 94025 , U.S.A.
}

oxidative recycling must have rendered marine waters relatively richer in ${ }^{13} \mathrm{C}$. Cenomanian-Turonian carbon-rich shales are recorded from a number of Pacific Ocean sites (e.g., Shatsky Rise, Hess Rise, Mariana Basin) that occupied peri-equatorial positions during that time, showing the impact of the oceanic anoxic event in this part of the globe (Schlanger et al., 1987).

Although the carbon-isotope excursion has been documented from the Atlantic, from outcrops on neighboring land masses, and, tentatively, from the Indian Ocean (Schlanger et al., 1987), there is a paucity of published data for the Pacific. The early work of Douglas and Savin (1975) from Hess and Shatsky rises concentrated on the oxygenisotope data in the context of paleotemperatures, and stratigraphic coverage was extremely limited. The more recent study of Boersma and Shackleton (1981) on foraminifers from Hess Rise and the Mid-Pacific Mountains dealt only with Turonian and higher stages.

The most detailed study of the carbon-isotope signatures, of not only the Cenomanian and Turonian, but higher Cretaceous stages as well, is that of Jenkyns et al. (1994), who investigated many chalk sections from southern Britain, as well as the coeval Scaglia facies cropping out near Gubbio in the Italian Apennines. The high-resolution English and Italian isotopic curves provide a reference against which the Pacific data can be compared. Moreover, differences in the absolute $\delta^{13} \mathrm{C}$ values are observed between these two European sections, implying incomplete mixing of watermasses between the Chalk Sea and the Tethyan continental margin. Thus, a record from half a world away might potentially shed some light on the nature of Cretaceous oceanic circulation.

\section{BIOSTRATIGRAPHY}

Biostratigraphy is illustrated in Figure 3. The calcareous nannofossils in Cores 143-869B-69R through -36R indicate a middle to late Cenomanian age. This assignment is based on the occurrence of two age-diagnostic species: Lithraphidites acutus, which is restricted to the middle and late Cenomanian elsewhere, and has been observed in Cores 143-869B-66R to -46R; and Corollithion kennedyi, which became extinct at the Cenomanian/Turonian boundary, and ranges from Cores 143-869B-69R through to -36R. Cores 143-869B-35R to -33R are, according to the calcareous nannofossils, of Turonian to early Coniacian age. This is indicated by the presence of both Eiffelithus eximius and Quadrum gartneri and the absence of Marthasterites 


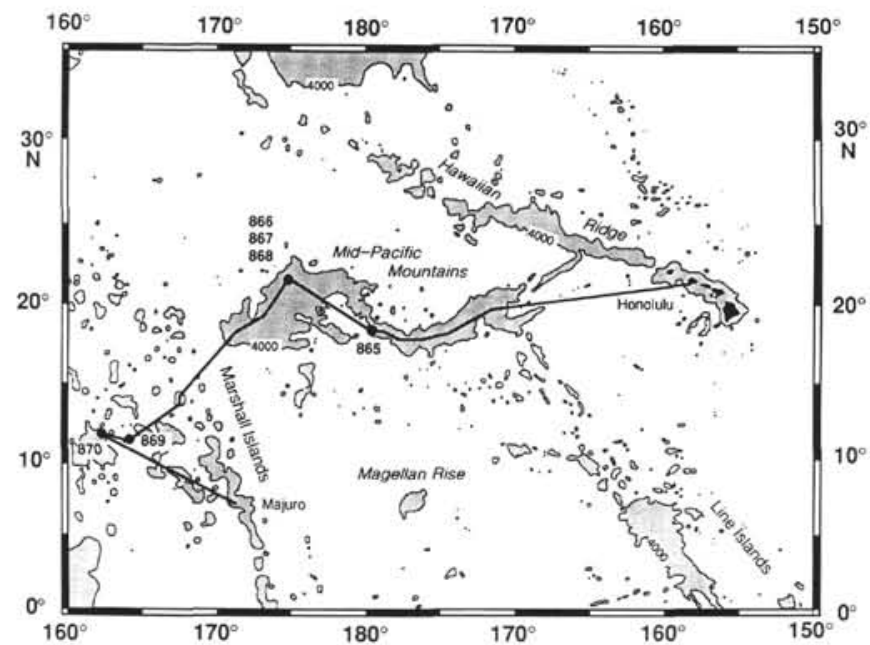

Figure 1. Map illustrating location of sites drilled during Leg 143. Site 869 is situated on the flank of Pikinni-Wodejebato, formerly Bikini-Sylvania, in the Marshall Islands.

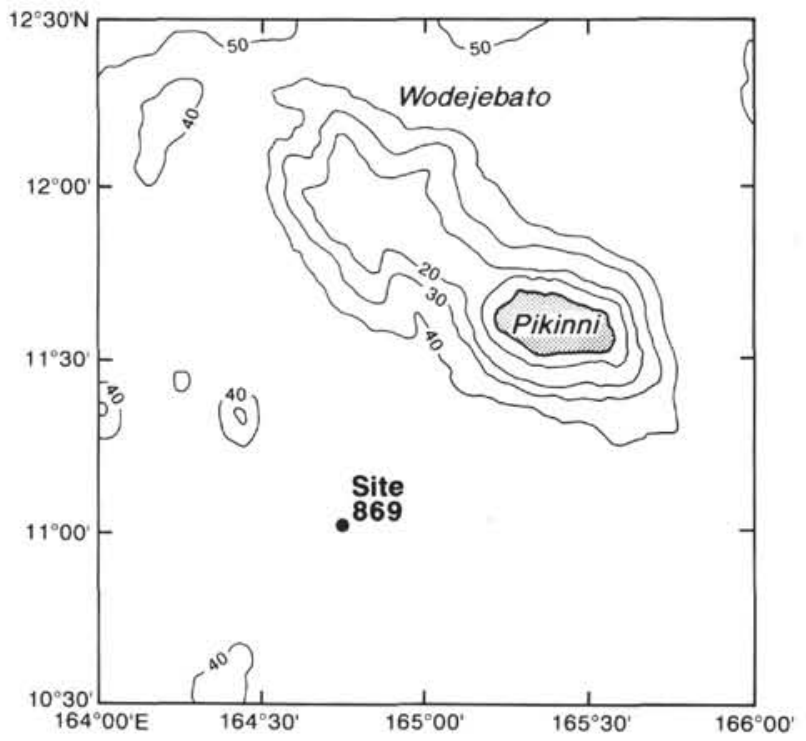

Figure 2. Detail showing location of Site 869 relative to Pikinni-Wodejebato. Bathymetric contours in hundreds of meters. The Cretaceous section comprises redeposited basaltic volcaniclastics bearing some derived shallow-water grains and containing intercalations of foraminiferal-nannofossil carbonate.

furcatus and Micula decussata. Sections 143-869B-32R-3 to -31R-1 are of Coniacian age, based on the co-occurrence of the primary markers $M$. furcatus and $Q$. gartneri and the absence of $M$. decussata. Samples 143-869B-30R-CC and -29R-CC are regarded as Santonian, as indicated by the presence of $M$. furcatus, $M$. decussata, $Q$. gartneri, and Lithastrinus grilli and the absence of Broinsonia parca parca. Cores 143-869B-28R to -26R have an early Campanian age; age-diagnostic species include Broinsonia parca parca, Quadrum gothicus and L. grilli. Bukryaster hayi, a species having a limited range in the Late Early Cretaceous, is present in Cores 143-869B-25R to -22R. Cores 143-869B-19R to -17R yielded Ceratolithoides aculeus and Ceratolithoides verbeeki. The presence of these two species, and the absence of Quadrum sissinghi and Q. gothicum, give this interval a late Campanian age. Cores 143-869B-16R to $-11 \mathrm{R}$ are regarded as late Campanian in age, since the secondary markers $Q$. sissinghi and $Q$. gothicum co-occur with $C$. aculeus and $C$. verbeeki, whereas the primary Quadrum trifidum is absent. Interval $143-869 \mathrm{~B}-10 \mathrm{R}-\mathrm{CC}$ to $-8 \mathrm{R}-\mathrm{CC}$ is

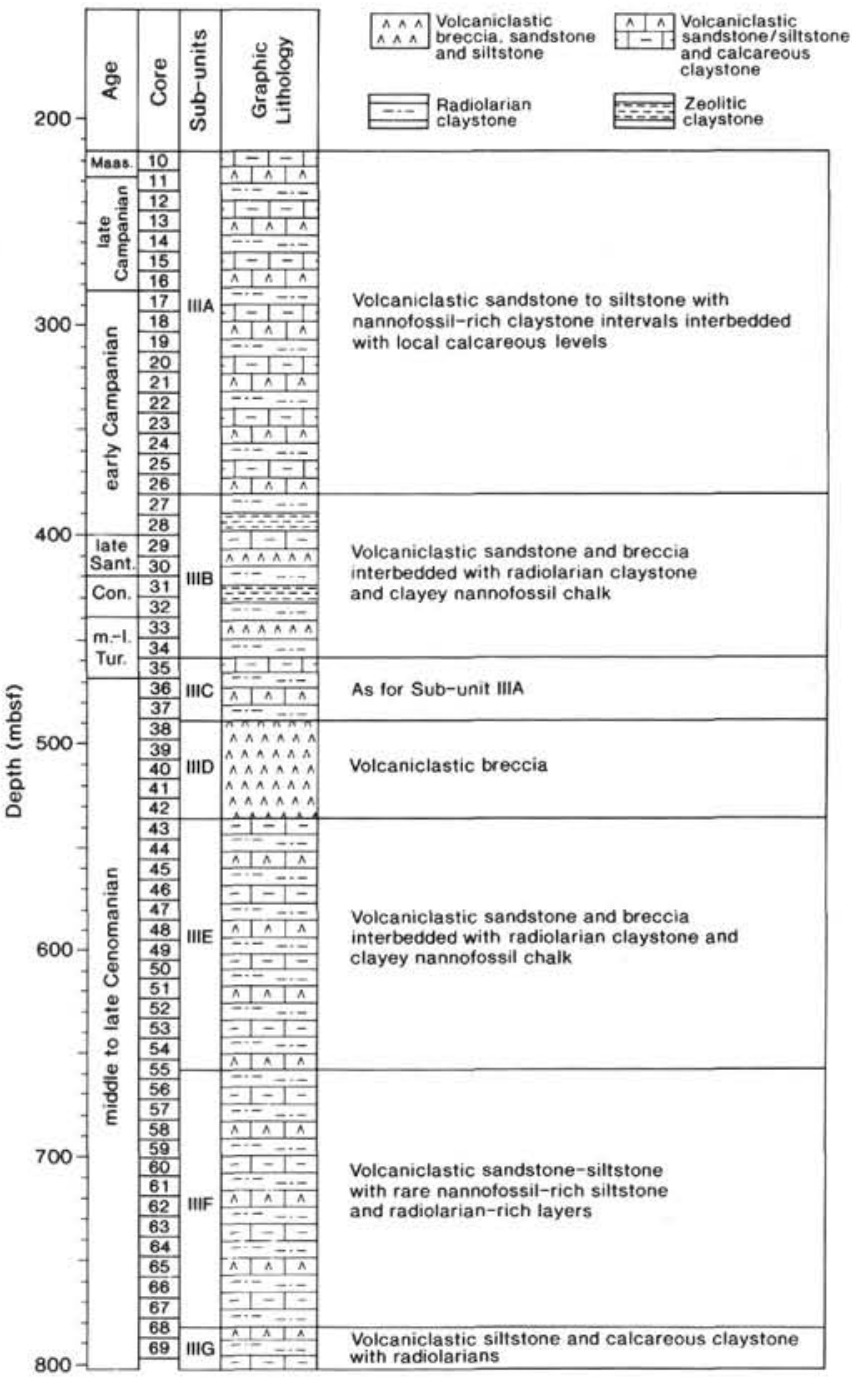

Figure 3. Part of sedimentary section cored at Site 869, showing principal facies set against stratigraphic age, depth-in-hole, and core numbers.

of latest Campanian to early Maastrichtian age, based on the presence of $Q$. trifidum in addition to $Q$. sissinghi and $Q$. gothicum.

Planktonic foraminiferal stratigraphy, based on study of washed samples and thin sections, indicates that the Cenomanian to Coniacian part of the sequence is well constrained by the presence of primary species; that the Santonian and Campanian is loosely constrained; and that the Maastrichtian again seems tight, based on well-known but secondary species. Cores $143-869 \mathrm{~B}-52 \mathrm{R}$ to $-36 \mathrm{R}$ are identified as middle to upper Cenomanian, Dicarinella algeriana Subzone of the Rotalipora cushmani Zone, based on the restricted ranges of the nominate species and $R$. greenhornensis, which became extinct at the Cenomanian/Turonian boundary. Cores $143-869 \mathrm{~B}-35 \mathrm{R}$ to $-34 \mathrm{R}$ are early Turonian in age, based on the total range of the nominate species for the Helvetoglobotruncana helvetica Zone. The Cenomanian/ Turonian boundary lies between Sections 143-869B-35R-1 and -36R3. Sample $143-869 \mathrm{~B}-31 \mathrm{R}-1,72-74 \mathrm{~cm}$, is early Coniacian in age, based on the presence of Dicarinella primitiva and the absence of $D$. concavata. This occurrence corresponds to the $D$. primitiva Zone of Caron (1985).

The Core 143-869B-30R assemblage is regarded as "no younger than Santonian," based on a meager group of planktonic foraminifers of secondary importance in chronostratigraphy and the known range of Heterohelix moremani, which does not extend into the Campanian. 
Cores 143-869B-11-CC to -28-CC are regarded as Campanian in age, based on those foraminifers present and the absence of younger forms. Species present, such as Globotruncana mariei, G. orientalis, $G$. ventricosa, Contusotruncana patelliformis, and Radotruncana subspinosa, first occur in the Campanian and range into the Maastrichtian. Globotruncana ventricosa is the nominate species for the middle to upper Campanian foraminiferal zone. Finally, the presence of Globotruncanita stuarti in Samples 143-869B-11R-1, 143-145 $\mathrm{cm}$, and -10R-CC indicates lower to upper Maastrichtian, based on the restricted range of this species. The presence of the questionable Globotruncana aegyptiaca in Sample 143-869B-10R-CC indicates a time span of late early to late Maastrichtian. These data are sparse, but the ranges for the latter two species are solely Maastrichtian.

\section{ANALYTICAL TECHNIQUES}

Bulk samples were obtained by scraping or cutting sufficient material from cores. Analyses from different positions within such specimens typically differed by less than $0.2 \%$ for $\delta^{18} \mathrm{O}$ and $\delta^{13} \mathrm{C}$, but clay-rich samples showed more variability. Samples were cleaned using $10 \% \mathrm{H}_{2} \mathrm{O}_{2}$, subsequently washed with acetone, and then dried at $60^{\circ} \mathrm{C}$. They then were reacted with purified orthophosphoric acid at $90^{\circ} \mathrm{C}$ and analyzed online using a VG Isocarb device and Prism mass spectrometer at Oxford University. Normal corrections were applied, and the results have been reported, using the usual $\delta$ notation, in per mil $(\%)$ deviation from the PDB standard. Calibration to PDB was performed with reference to the laboratory standard calibrated against NBS19 and Cambridge Carrara marble. Reproducibility of replicate analyses of standards was generally better than $0.1 \%$ for both carbon- and oxygen-isotope ratios.

\section{RESULTS}

The oxygen- and carbon-isotope data are illustrated in Figure 4. For comparison, smoothed data from the English Chalk and Italian Scaglia, with appropriate stratigraphy, are presented in Figure 5. In this latter figure, note that the stage boundaries defined by macrofossils, as seen in the Chalk, and by microfossils, as seen in the Scaglia, differ somewhat, particularly in the case of the Turonian, Coniacian, and Santonian stages.

Although the data coverage for Site 869 is somewhat limited, the basic shape of the curve for the Cenomanian through Santonian stages is readily recognizable and compares not unfavorably with the $\delta^{13} \mathrm{C}$ profiles of the European sections. In all three places, values rise from around $2 \%$, decline slightly to form a step at a level of $2.5 \%$, then rise to reach a maximum above $3 \%$ (Cenomanian/Turonian boundary) fall, step up, then fall again, through another step, to reach a minimum of between 1 and $2 \%$, depending on the section concerned. Values then rise again, through some small peaks, into the Campanian, where values are between 2 and $3 \%$.

Intercomparisons among the three curves and the available stratigraphy indicate some discrepancies. In all three examples, the biostratigraphically defined Cenomanian/Turonian boundary is equally fixed by the position of the highest carbon-isotope peak; the lowest value falls in the Coniacian stage in the Sylvania-Wodejebato and Gubbio sequences, where defined by microfossils and nannofossils, and in the Turonian in the Chalk section, where defined by macrofossils. The broad plateau, dated as late Coniacian or Santonian in the English and Italian sections, respectively, is not recognizable in the Santonian-Campanian of Hole 869B: unfortunately, in the latter case, few data points exist owing to poor recovery of this interval. Note that the peak values at the Cenomanian/Turonian boundary in the Pacific and Gubbio sections are somewhat damped relative to those from the European Chalk, which typically fall in the range of 4 to $5 \%$.

The Campanian-Maastrichtian part of the section exhibits two major negative excursions (Fig. 4). The significance of these is not entirely clear. Certainly, in the case of the stratigraphically lower of
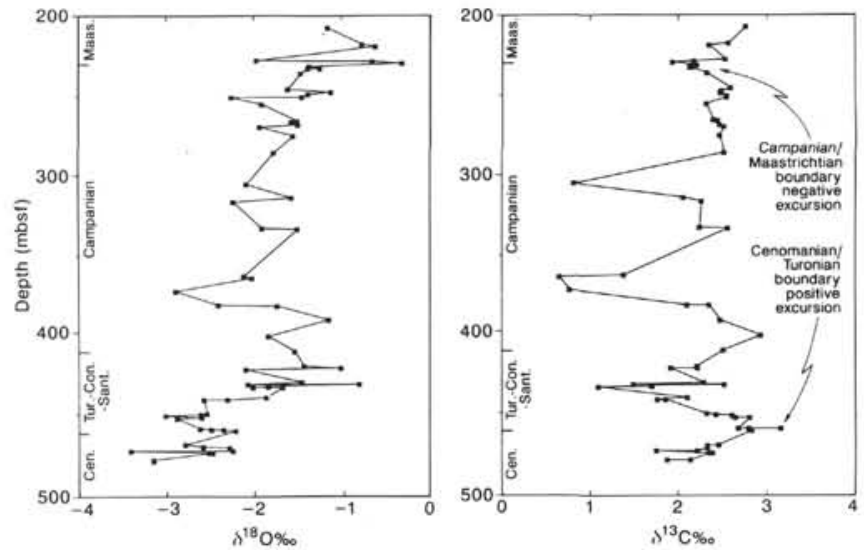

Figure 4. Oxygen- and carbon-isotope stratigraphy of the Upper Cretaceous section from Site 869 .

the two, there is some correlation with the oxygen isotopes, which is suggestive of strong diagenetic overprinting. These two negative excursions apart, the $\delta^{13} \mathrm{C}$ Campanian profile is unremarkable, except for a feature close to the boundary with the Maastrichtian stage, where another, minor negative excursion is defined by half a dozen points and shows no correlation with the $\delta^{18} \mathrm{O}$ values. At Site 465 on the southern Hess Rise, sparse carbon-isotope data from benthic foraminifers also define a decrease in values across the stage boundary (Boersma and Shackleton, 1981). A similar feature of comparable magnitude has been recorded from benthic and planktonic foraminifers of late early Maastrichtian age sampled from ODP sites off the coast of East Antarctica (Barrera and Huber, 1990). Conceivably, this is registering the same event, bearing in mind stratigraphic uncertainties; if so, this would suggest the presence of a hiatus at the base of the recovered interval at Site 869 . It is notable also that the Maastrichtian in Site 869 is not well defined biostratigraphically. Campanian $\delta^{13} \mathrm{C}$ profiles from the English chalk show a negative excursion high in the stage (Scholle and Arthur, 1980; Jenkyns et al., 1994), and this might also be what is being registered in the SylvaniaWodejebato profile. As English Chalk stratigraphy at these levels is founded on belemnites, what is regarded as late Campanian on a macrofossil time scale is considered as early Maastrichtian on microfossil and nannofossil time scales (Burnett et al., 1992). Further research will be necessary to establish the regional extent of this negative $\delta^{13} \mathrm{C}$ shift and its possible significance in correlation.

The oxygen-isotope data (Fig. 4) show a minimum near the Cenomanian/Turonian boundary and, then, possible diagenetic excursions apart, rise to heavier values. This is exactly the signature seen in the English Chalk, where it has been interpreted as related to climatic deterioration following the Cenomanian-Turonian oceanic anoxic event (Jenkyns et al., 1994). Oxygen-isotope values from single foraminifers and nannofossils from other Pacific Ocean DSDP sites exhibit the same general trend (Douglas and Savin, 1975; Boersma and Shackleton, 1981).

\section{CONCLUSIONS}

The carbon- and oxygen-isotope stratigraphy of Site 869 (flank of Pikinni-Wodejebato) shows profiles similar to those documented from the mid- to Upper Cretaceous of other parts of the globe, indicating that Pacific watermasses had essentially the same isotopic chemistry as the Atlantic/Tethyan oceans and European shelf seas. Characteristic $\delta^{13} \mathrm{C}$ signatures of oceanic anoxic events (regional carbon-burial episodes) are recognizable, as is the post-Cenomanian heavier $\delta^{18} \mathrm{O}$ trend, indicating climatic decline. A negative $\delta^{13} \mathrm{C}$ excursion close to the Campanian/Maastrichtian boundary in Site 869 may have regional significance. 
A Smoothed data : Chalk

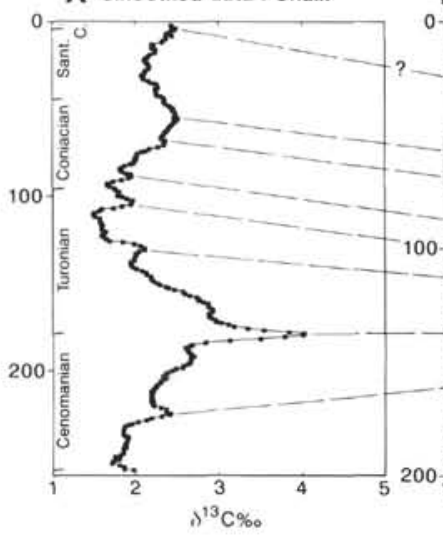

B Smoothed data : Scaglia
C Primary data : Site 869

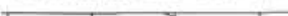

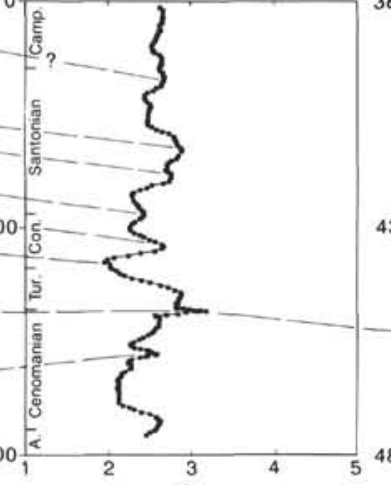

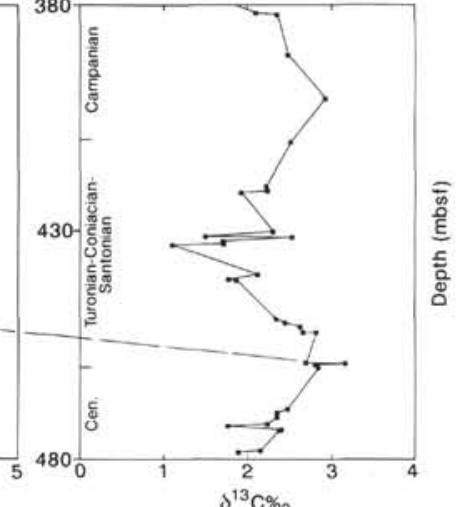

Figure 5. Comparative carbon-isotope stratigraphy. Smoothed (five-point moving average) $\delta^{13} \mathrm{C}$ profiles of the Cenomanian/Campanian interval through the English Chalk (A) of East Kent, England, and the Scaglia facies (B), Marche-Umbrian Apennines, Italy (Jenkyns et al., 1994), compared with primary data from Site 869 (C). The paucity of pelagic carbonate in the deep-water Pacific section means that relatively few data points exist, but a number of features of the three curves, particularly the Cenomanian/Turonian boundary positive excursion, are comparable. The depth scale for Site 869 is shown as meters below seafloor; for the two other sections, the depth is in meters below an arbitrary datum.

\section{REFERENCES}

Arthur, M.A., Brumsack, H.-J., Jenkyns, H.C., and Schlanger, S.O., 1990. Stratigraphy, geochemistry, and paleoceanography of organic carbon-rich Cretaceous sequences. In Ginsburg, R.N., and Beaudoin, B. (Eds.), Cretaceous Resources, Events and Rhythms. NATO ASI Ser., 75-119.

Barrera, E., and Huber, B.T., 1990. Evolution of Antarctic waters during the Maastrichtian: foraminifer oxygen and carbon isotope ratios, Leg 113. In Barker, P.F., Kennett, J.P., et al., Proc. ODP, Sci. Results, 113: College Station, TX (Ocean Drilling Program), 813-827.

Boersma, A., and Shackleton, N.J., 1981. Oxygen- and carbon-isotope variations and planktonic foraminifer depth habitat, Late Cretaceous to Paleocene, Central Pacific. In Thiede, J., Vallier, T.L., et al., Init. Repts. DSDP, 62: Washington (U.S. Govt. Printing Office), 513-526.

Burnett, J.A., Hancock, J.M., Kennedy, W.J., and Lord, A.R., 1992. Macrofossil, planktonic foraminiferal and nannofossil zonation at the Campanian/Maastrichtian boundary. Newsl. Stratigr., 27:157-172.

Caron, M., 1985. Cretaceous planktonic foraminifera. In Bolli, H.M., Saunders, J.B., and Perch-Nielsen, K. (Eds.), Plankton Stratigraphy: Cambridge (Cambridge Univ. Press), 17-86.

Douglas, R.G., and Savin, S.M., 1975. Oxygen and carbon isotope analyses of Tertiary and Cretaceous microfossils from Shatsky Rise and other sites in the North Pacific Ocean. In Larson, R.L., Moberly, R., et al., Init. Repts. DSDP, 32: Washington (U.S. Govt. Printing Office), 509-520.

Gale, A.S., Jenkyns, H.C., Kennedy, W.J., and Corfield, R.M., 1993. Chemostratigraphy versus biostratigraphy: data from around the CenomanianTuronian boundary. J. Geol. Soc. London, 150:29-32.

Jarvis, I., Carson, G.A., Cooper, M.K., Hart, M.B., Leary, P.N., Tocher, B.A., Horne, D., and Rosenfeld, A., 1988. Microfossil assemblages and the Cenomanian-Turonian (late Cretaceous) oceanic anoxic event. Cretaceous Res., 9:3-103.

Jenkyns, H.C., 1980. Cretaceous anoxic events: from continents to oceans. $J$. Geol. Soc. London, 137:171-188.
Jenkyns, H.C., Gale, A.S., and Corfield, R.M., 1994. Carbon- and oxygenisotope stratigraphy of the English Chalk and Italian Scaglia and its palaeoclimatic significance. Geol. Mag., 131:1-34.

Kuhnt, W., Herbin, J.P., Thurow, J., and Wiedmann, J., 1990. Distribution of Cenomanian-Turonian organic facies in the western Mediterranean and along the adjacent Atlantic margin. In Huc, A.Y. (Ed.), Deposition of Organic Facies. AAPG Stud. in Geol., 30:133-160.

Pratt, L.M., and Threlkeld, C.N., 1984. Stratigraphic significance of ${ }^{13} \mathrm{C} /{ }^{12} \mathrm{C}$ ratios in mid-Cretaceous rocks of the Western Interior, U.S.A. In Stott, D.F., and Glass, D.J. (Eds.), The Mesozoic of Middle North America. Mem.-Can. Soc. Pet. Geol., 9:305-312.

Sager, W.W., Winterer, E.L., Firth, J.V., et al., 1993. Proc. ODP, Init. Repts., 143: College Station, TX (Ocean Drilling Program).

Schlanger, S.O., Arthur, M.A., Jenkyns, H.C., and Scholle, P.A., 1987. The Cenomanian-Turonian Oceanic Anoxic Event, I. Stratigraphy and distribution of organic carbon-rich beds and the marine $\delta^{13} \mathrm{C}$ excursion. In Brooks, J., and Fleet, A.J. (Eds.), Marine Petroleum Source Rocks. Geol. Soc. Spec. Publ. London, 26:371-399.

Scholle, P.A., and Arthur, M.A., 1980. Carbon isotope fluctuations in Cretaceous pelagic limestones: potential stratigraphic and petroleum exploration tool. AAPG Bull., 64:67-87.

\footnotetext{
Abbreviations for names of organizations and publications in ODP reference lists follow the style given in Chemical Abstracts Service Source Index (published by American Chemical Society).
}

Date of initial receipt: 8 November 1993

Date of acceptance: 11 April 1994

Ms 143SR-214 